\title{
Article \\ Durability Performance of Self-Compacting Concrete Containing Crumb Rubber, Fly Ash and Calcium Carbide Waste
}

\author{
Sylvia E. Kelechi ${ }^{1,2}$, Musa Adamu ${ }^{2,3, * \mathbb{D}}$, Abubakar Mohammed ${ }^{2}$ D, , Yasser E. Ibrahim ${ }^{3, *(D)}$ \\ and Ifeyinwa I. Obianyo 4 (D)
}

1 Department of Mechanical and Civil Engineering, Purdue University Northwest, Hammond, IN 46323, USA; skelechi@pnw.edu

2 Department of Civil Engineering, Bayero University, P.M.B 3011, Kano 700006, Nigeria; amohammed.civ@buk.edu.ng

3 Engineering Management Department, College of Engineering, Prince Sultan University, Riyadh 11586, Saudi Arabia

4 Department of Materials Science and Engineering, African University of Science and Technology, Abuja 900109, Nigeria; iobianyo@aust.edu.ng

* Correspondence: madamu.civ@buk.edu.ng or madamu@psu.edu.sa (M.A.); ymansour@psu.edu.sa (Y.E.I.)

Citation: Kelechi, S.E.; Adamu, M.; Mohammed, A.; Ibrahim, Y.E.; Obianyo, I.I. Durability Performance of Self-Compacting Concrete Containing Crumb Rubber, Fly Ash and Calcium Carbide Waste. Materials 2022, 15, 488. https:// doi.org/10.3390/ma15020488

Academic Editor: Karim Benzarti

Received: 14 December 2021

Accepted: 7 January 2022

Published: 9 January 2022

Publisher's Note: MDPI stays neutral with regard to jurisdictional claims in published maps and institutional affiliations.

Copyright: (C) 2022 by the authors. Licensee MDPI, Basel, Switzerland. This article is an open access article distributed under the terms and conditions of the Creative Commons Attribution (CC BY) license (https:// creativecommons.org/licenses/by/ $4.0 /)$.

\begin{abstract}
Waste tire disposal continues to pose a threat to the environment due to its non-biodegradable nature. Therefore, some means of managing waste tires include grinding them to crumb rubber (CR) sizes and using them as a partial replacement to fine aggregate in concrete. However, the use of CR has a series of advantages, but its major disadvantage is strength reduction. This leads to the utilization of calcium carbide waste (CCW) to mitigate the negative effect of $\mathrm{CR}$ in self-compacting concrete (SCC). This study investigates the durability properties of SCC containing CR modified using fly ash and CCW. The durability properties considered are water absorption, acid attack, salt resistance, and elevated temperature of the mixes. The experiment was conducted for mixes with no-fly ash content and their replica mixes containing fly ash to replace $40 \%$ of the cement. In the mixes, CR was used to partially replace fine aggregate in proportions of $0 \%, 10 \%$, and $20 \%$ by volume, and CCW was used as a partial replacement to cement at $0 \%, 5 \%$, and $10 \%$ by volume. The results indicate that the mixes containing fly ash had higher resistance to acid $\left(\mathrm{H}_{2} \mathrm{SO}_{4}\right)$ and salt $\left(\mathrm{MgSO}_{4}\right)$, with up to $23 \%$ resistance observed when compared to the mix containing no fly ash. In addition, resistance to acid attack decreased with the increase in the replacement of fine aggregate with CR. The same principle applied to the salt attack scenario, although the rate was more rapid with the acid than the salt. The results obtained from heating indicate that the weight loss was reduced slightly with the increase in CCW, and was increased with the increase in CR and temperature. Similarly, the compressive strength was observed to slightly increase at room temperature $\left(27^{\circ} \mathrm{C}\right)$ and the greatest loss in compressive strength was observed between the temperature of 300 and $400{ }^{\circ} \mathrm{C}$. However, highest water absorption, of $2.83 \%$, was observed in the mix containing $20 \% \mathrm{CR}$, and $0 \% \mathrm{CCW}$, while the lowest water absorption, of $1.68 \%$, was found in the mix with $0 \% \mathrm{CR}, 40 \%$ fly ash, and $10 \% \mathrm{CCW}$. In conclusion, fly ash is recommended for concrete structures immersed in water, acid, or salt in sulphate- and magnesium-prone areas; conversely, fly ash and CR reduce the resistance of SCC to heat beyond $200{ }^{\circ} \mathrm{C}$.
\end{abstract}

Keywords: calcium carbide residue; crumb rubber; fly ash; self-compacting concrete; acid attack; salt attack

\section{Introduction}

Environmental pollution causes a great danger to human health as well as contributing to the risk of the climate change. Efficient waste management has become increasingly essential since the industrial revolution. In the recent past, researchers have focused on the valorization of waste materials by turning them into wealth [1]. These waste materials 
could be recycled and reused for the development of other useful materials [2]. Cement is one of the most utilized construction materials due to its availability, but its production seriously affects environmental sustainability through the emission of high amounts of greenhouse gases such as $\mathrm{CO}_{2}$. The use of waste materials and by-products that have cementitious and Pozzolanic properties will significantly reduce the demand for cement in the construction industry and hence lower the $\mathrm{CO}_{2}$ emissions resulting from cement production [3].

Calcium carbide is a dangerous and corrosive waste material obtained as a by-product during the production of acetylene $\left(\mathrm{C}_{2} \mathrm{H}_{2}\right)$ gas [4-6], whereas crumb rubber $(\mathrm{CR})$ is produced from used tires (waste tires) that have been abandoned at mechanic shops and dumpsites [7]. On the other hand, fly ash is a waste material generated from coal-fired electric- and steam-generating plants during coal combustion. In a bid to add value to these waste materials as well as to curb the environmental issues associated with the dumping of these wastes, researchers have been exploring ways to recycle and reuse them efficiently. The use of CR as an aggregate replacement in concrete has been necessitated by the continual increase in the demand for concrete aggregates, with its associated environmental impacts. The environmental impact of using conventional aggregates could lead to erosion, landslides, and natural resource depletion (global warming). The utilization of CR as an aggregate in concrete is eco-friendly and would prevent the burning of used tires, which causes air pollution. Thus, the use of these eco-friendly aggregates in concrete has the potential to mitigate global warming through the prevention of the burning of these waste tires, which releases greenhouse gases into the atmosphere [8].

Research works on the utilization of CCW as well as CR in the production of selfcompacting concrete (SCC) have been published [9-11].

The durability of SCC is a vital parameter to consider in order to ensure a longer lifespan of the structures constructed with it. This parameter relates to the ability of SCC to retain its original shape, dimension, and quality during its estimated service life when subjected to the toughest weathering conditions, abrasion, and diverse chemical attacks. Tests such as chloride attack/acid attack, sulphate resistance, water absorption, and porosity tests are conducted when assessing the durability of SCC. Several studies have been conducted on the durability of conventional concrete, with a few focused on conventional SCC and very little research conducted on SCC ternary blends. Rajamony Laila et al. [12] investigated the effect of super absorbent polymer (SAP) on the durability and mechanical performance of SCC. They replaced cement using granite Pulver (GP) at 5 to $20 \%$ by weight. They used the SAP at 0.1 to $1 \%$ by volume fraction of the GP-SCC mixtures. Their results showed that SAP decreased the filling ability and flowability of the SCC. Furthermore, GP increased the early strength development of the SCC at 7 days. The addition of 0.3 and $0.4 \%$ SAP significantly improved the flexural, compressive, and splitting tensile strengths of the SCC. In terms of durability, GP improved the resistance of the SCC to acid and sulphate attack. They concluded that up to $15 \%$ cement can be replaced by using GP to improve the durability and mechanical properties of the SCC. In another study, Rajamony Laila et al. [13] utilized GP and SAP in conventional concrete and reported similar findings. A study by Surya et al. [14] on the compressive strength of SCC was carried out under elevated temperatures. It was found that as the temperature increases, the compressive strength is decreased. Furthermore, the decrease in the compressive strength was found to be greater at $600{ }^{\circ} \mathrm{C}$ and $800{ }^{\circ} \mathrm{C}$, conversely to the effects observed at $200{ }^{\circ} \mathrm{C}$ and $400^{\circ} \mathrm{C}$. The study concluded that higher elevated temperature has a negative effect on the compressive strength of SCC. According to Santos et al. [15], an increase in the percentage of recycled coarse aggregate increased chlorine penetration depths. SCC mixes containing $40 \%$ recycled coarse aggregate were reported to show better resistance to chloride penetration and acid attack in this study. However, research by Yehia et al. [16] presented low chloride permeability for all mixes, which is an indication of the satisfactory durability of SCC and fiber-reinforced SCC. The low chlorine penetration obtained from their studies was attributed to the high density of the mix. In addition, Babu and Nazeer [17] 
reported optimum resistance to chloride-ion penetration for SCC ternary blend specimens with $10 \%$ silica fume replacement. The results of their studies indicated that there was a high sulphate attack resistance for ternary blended concrete with $5 \%$ replacement of silica fumes.

Research carried out by Danish and Ganesh [18] established that the addition of metakaolin and fly ash in SCC mixes reduces water absorption. This could be attributed to the ability of the metakaolin and fly ash to act as fillers by improving the microstructure of the SCC. It was observed that the control mix gave the highest water absorption of $4.84 \%$ and $4.04 \%$ at 28 and 90 days, respectively, while the incorporation of $15 \%$ metakaolin resulted in a lower water absorption of $2.02 \%$ and $1.60 \%$ at 28 and 90 days, respectively. Hence, the incorporation of metakaolin in the SCC mix resulted in a positive effect of decreasing the water absorption of the mix. Another investigation by Santos et al. [15] showed that the incorporation of a high amount of recycled coarse aggregate in SCC mixes displayed a high initial water absorption level that led to an increase in the permeability values of the mix. The results of the review conducted on the use of waste tire rubber in concrete showed that the water absorption of both SCC and traditional concrete was increased on the addition of waste tire rubber due to the rubber particles' rough surfaces. It was also speculated that increasing the water/cement ratio will increase water absorption [19].

The addition of admixtures such as metakaolin and fly ash has a positive influence on the porosity in SCC mixes [18]. A concrete mix with an increased porosity network tends to result in a decreased strength of the mix as well as a reduced durability $[8,20]$. Bayuaji et al. [21] investigated the properties of geopolymer paste produced with CCW and fly ash. The results of their research indicated that samples with the highest level of CCW and fly ash showed the lowest porosity at an age of 56 days. Abdurra'uf et al. [22] also reported an increased porosity in mortar with the increase in the CCW content when used as a cement replacement in mortar. A review conducted by Bušić et al. [19] indicated that an increase in rubber aggregate content in SCC mixtures resulted in an increase in porosity and air content of the mix due to the entrapment of air in the interfacial transition zone between the cement paste and rubber particles.

Furthermore, CCW has been used for soil modification and stabilization [23,24]. Fly ash has also been utilized and recommended by researchers for the partial replacement of cement in concrete $[18,25,26]$. For the purpose of environmental sustainability, specifically to achieve a reduction in the pollution of the environment and a reduction in the demand for natural materials such as aggregates in concrete, $C R$ has been used to partially replace fine or coarse aggregate in concrete. In SCC, CR has been used to partially replace fine aggregate. Several researchers reported the positive effect of the CR in SCC. For example, Hilal [9] reported an improvement in the fracture energy of SCC with the replacement of up to $5 \%$ of fine aggregate with $C R$, and improved ductility with the replacement of up to $25 \%$ of fine aggregate using CR. Najim and Hall [27] also reported a significant improvement in the strain energy of SCC, which resulted in reduced crack mouth open displacement. Additionally, they reported an improvement in ductile behavior, energy absorption, and vibration damping in SCC with the replacement of fine aggregate with CR. Khalil et al. [28] reported an improvement in the impact resistance of SCC when up to $30 \%$ of fine aggregate was replaced with CR. In a similar study, Adamu et al. [29] also reported improved impact resistance with the replacement of up to $30 \%$ of fine aggregate in concrete. However, the major disadvantage of using CR in concrete and SCC is the reduction in mechanical properties and durability performance. These reductions in mechanical properties and durability are more severe with the increment in CR content, as reported in several studies $[9,27,30]$.

As reported, both fly ash and CR have significant advantages when used in SCC; these include a reduction in the cost of the concrete, greater environmental and material sustainability, and improved waste management. However, their main disadvantages include a reduction in the mechanical properties and durability of SCC due to their negative effects. Therefore, in this study, CCW was used as an additive by weight of cementitious 
materials to mitigate the negative effect of CR on the durability of SCC and activate the pozzolanic reaction of fly ash at early ages to improve the durability of SCC. Additionally, the use of a combination of the three materials (CCW, CR, and fly ash) to produce an environmentally sustainable SCC is yet to be fully explored. Therefore, the objective of this study was to investigate the durability properties of rubberized SCC containing CCW and fly ash as supplementary cementitious materials in normal and adverse conditions. In this research, water absorption, acid resistance, sulphate resistance, and heat resistance tests were carried out to determine the durability of the blended rubberized SCC.

\section{Materials and Methods}

\subsection{Materials}

Type 1 Ordinary Portland cement with a specific gravity of 3.5, conforming to the guidelines outlined in BS EN 196-6 [31], was used as the main binder material in this study. The cement has chemical properties, which were established using X-ray Fluorescence and are presented in Table 1. Class F fly ash, conforming to the requirements of ASTM C618 [32], was used as a supplementary cementitious material. The properties of the fly ash are also presented in Table 1. The CCW was collected from a commercial welding workshop disposal site in Kano, Nigeria. After that, it was first air dried for about four days and then oven dried for $24 \mathrm{~h}$ at a temperature of $110 \pm 5^{\circ} \mathrm{C}$ to make it completely dry. The CCW was then ground in a grinding machine and sieved through a No. 325 (45 $\mu \mathrm{m})$ sieve. The particles retained on the sieve were discarded and the ones that passed through were used. The properties of the CCW were then determined using XRF analysis and the results are presented in Table 1 . The fine aggregate used was natural river sand, with a specific gravity of 2.63 , a bulk density of $1560 \mathrm{~kg} / \mathrm{m}^{3}$, a water absorption rate of $1.96 \%$, and a mud content of $1.1 \%$. The particle size distribution of the fine aggregate is presented in Figure 1, and belongs to the zone II class based on the grading limit of BS 882 [33]. The CR used had a specific gravity of 0.95 , and particle size distribution similar to that of the fine aggregate, as shown in Figure 1. Crushed granite with a maximum size of $19 \mathrm{~mm}$ was used as the coarse aggregate. The coarse aggregate had a specific gravity of 2.65 , a bulk density of $1450 \mathrm{~kg} / \mathrm{m}^{3}$, and a water absorption rate of $0.94 \%$; its particle size distribution is shown in Figure 1. A high-range water-reducing admixture was added by weight of cementitious materials to achieve the self-compaction. The dosage of the superplasticizer was used based on the manufacturer's specification of 2 to $15 \mathrm{fl.oz} / \mathrm{cwt}$ of cementitious materials.

Table 1. Chemical properties of materials.

\begin{tabular}{cccc}
\hline & \multicolumn{3}{c}{ Chemical Compositions (\%) } \\
\cline { 2 - 4 } Oxide & Cement & CCW & Fly Ash \\
\hline $\mathrm{SiO}_{2}$ & 12.00 & 1.10 & 52.06 \\
$\mathrm{Al}_{2} \mathrm{O}_{3}$ & 3.01 & 0.04 & 30.48 \\
$\mathrm{Fe}_{2} \mathrm{O}_{3}$ & 4.11 & 0.50 & 4.47 \\
$\mathrm{CaO}$ & 74.03 & 96.46 & 5.62 \\
$\mathrm{MgO}$ & 1.30 & - & 1.32 \\
$\mathrm{~K}_{2} \mathrm{O}$ & 1.28 & 0.45 & 1.54 \\
$\mathrm{Na}_{2} \mathrm{O}$ & 0.19 & 0.01 & 0.99 \\
$\mathrm{SO}_{3}$ & 2.07 & 0.29 & 2.1 \\
Loss of Ignition & 1.02 & 2.24 & 0.95 \\
Specific Gravity & 3.15 & 2.22 & 2.27 \\
Specific Surface Area (m & 29 & 29 & 290 \\
\hline
\end{tabular}




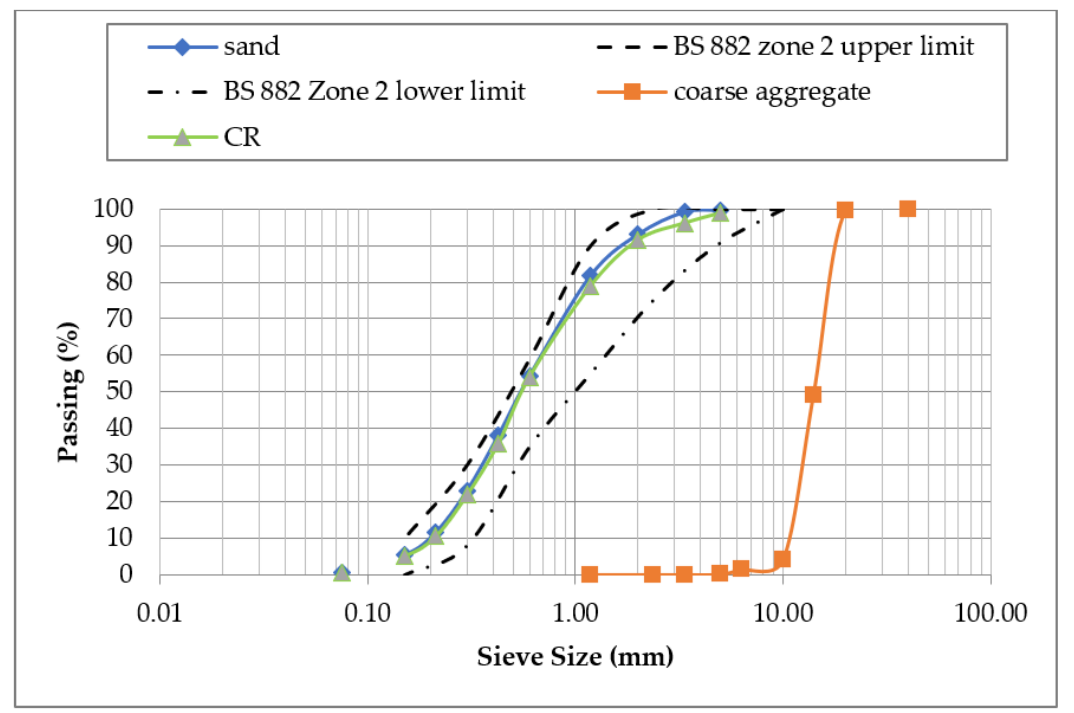

Figure 1. Particle size distribution of coarse aggregate.

\subsection{Mix Proportioning}

To examine the effect of CR and CCW on the durability performance of SCC under normal and adverse conditions, mixes were prepared by partially replacing fine aggregate with CR at $0 \%, 10 \%$, and $20 \%$ using a volume replacement method, and CCW was used as a partial replacement to cement at $0 \%, 5 \%$, and $10 \%$ by means of a volume replacement method. To further study the effect of fly ash on the durability of SCC blends, fly ash was used to replace $40 \%$ cement, with CR replacing fine aggregate at $0 \%, 10 \%$, and $20 \%$ by volume, and CCW replacing cement at $0 \%, 5 \%$, and $10 \%$ by volume. A total of eighteen mixes were prepared, as presented in Table 2 . The mixes were tested for acid attack, salt attack, elevated temperature, and water absorption. Each mix was assigned a unique ID; for example, mix M0CR0C is the control mix with $0 \% \mathrm{CR}$ and $0 \% \mathrm{CCW}$, and mix M0CR40F0C is the mix with $0 \%$ CR, 40\% fly ash, and $0 \%$ CCW. Mix M10CR5C is the mix with $10 \%$ CR and 5\% CCW, and mix M20CR40F10C is the mix with 10\% CR, 40\% fly ash, and 10\% CCW. The superplasticizer dosage used was $1.5 \%$ by weight of binder materials.

Table 2. Mix Proportioning.

\begin{tabular}{|c|c|c|c|c|c|c|c|c|c|}
\hline Mix ID & $\begin{array}{l}\text { Cement } \\
\left(\mathrm{kg} / \mathrm{m}^{3}\right)\end{array}$ & $\begin{array}{c}\mathrm{CCW} \\
\left(\mathrm{kg} / \mathrm{m}^{3}\right)\end{array}$ & $\begin{array}{l}\text { Fly Ash } \\
\left(\mathrm{kg} / \mathrm{m}^{3}\right)\end{array}$ & $\begin{array}{c}\text { Fine } \\
\text { Aggregate } \\
\left(\mathrm{kg} / \mathrm{m}^{3}\right)\end{array}$ & $\begin{array}{c}\text { CR } \\
\left(\mathrm{kg} / \mathrm{m}^{3}\right)\end{array}$ & $\begin{array}{c}\text { Coarse } \\
\text { Aggregate } \\
\left(\mathrm{kg} / \mathrm{m}^{3}\right)\end{array}$ & $\begin{array}{c}\text { Water } \\
\left(\mathrm{kg} / \mathrm{m}^{3}\right)\end{array}$ & $\begin{array}{c}\mathrm{SP} \\
\left(\mathrm{kg} / \mathrm{m}^{3}\right)\end{array}$ & W/B \\
\hline MOCROC & 520 & 0 & 0 & 880 & 0 & 850 & 192.4 & 7.80 & 0.37 \\
\hline M0CR40F0C & 312 & 0 & 149.89 & 880 & 0 & 850 & 192.4 & 6.93 & 0.42 \\
\hline M0CR5C & 494 & 18.32 & 0 & 880 & 0.00 & 850 & 192.4 & 7.68 & 0.38 \\
\hline M0CR40F5C & 286 & 18.32 & 149.89 & 880 & 0.00 & 850 & 192.4 & 6.81 & 0.42 \\
\hline M0CR10C & 468 & 36.65 & 0 & 880 & 0.00 & 850 & 192.4 & 7.59 & 0.38 \\
\hline M0CR40F10C & 260 & 36.65 & 149.89 & 880 & 0.00 & 850 & 192.4 & 6.70 & 0.43 \\
\hline M10CR0C & 520 & 0.00 & 0 & 792 & 38.25 & 850 & 192.4 & 7.80 & 0.37 \\
\hline M10CR40F0C & 312 & 0.00 & 149.89 & 792 & 38.25 & 850 & 192.4 & 6.93 & 0.42 \\
\hline M10CR5C & 494 & 18.32 & 0 & 792 & 38.25 & 850 & 192.4 & 7.68 & 0.38 \\
\hline M10CR40F5C & 286 & 18.32 & 149.89 & 792 & 38.25 & 850 & 192.4 & 6.81 & 0.42 \\
\hline M10CR10C & 468 & 36.65 & 0 & 792 & 38.25 & 850 & 192.4 & 7.59 & 0.38 \\
\hline M10CR40F10C & 260 & 36.65 & 149.89 & 792 & 38.25 & 850 & 192.4 & 6.70 & 0.43 \\
\hline M20CR0C & 520 & 0.00 & 0 & 704 & 76.49 & 850 & 192.4 & 7.80 & 0.37 \\
\hline M20CR40F0C & 312 & 0.00 & 149.89 & 704 & 76.49 & 850 & 192.4 & 6.93 & 0.42 \\
\hline M20CR5C & 494 & 18.32 & 0 & 704 & 76.49 & 850 & 192.4 & 7.68 & 0.42 \\
\hline M20CR40F5C & 286 & 18.32 & 149.89 & 704 & 76.49 & 850 & 192.4 & 6.81 & 0.42 \\
\hline M20CR10C & 468 & 36.65 & 0 & 704 & 76.49 & 850 & 192.4 & 7.59 & 0.38 \\
\hline M20CR40F10C & 260 & 36.65 & 149.89 & 704 & 76.49 & 850 & 192.4 & 6.70 & 0.43 \\
\hline
\end{tabular}




\subsection{Casting of Specimen}

The batching, mixing, and sampling of the fresh concrete was carried out in accordance with the guidelines outlined in BS 1881-125 [34]. A rotating pan mixer was used for the mixing of the fresh concrete. Before mixing, it was ensured that the cement, fly ash, and CCW were completely dried and free from lumps, and that the aggregates were in saturated surface dry condition to avoid the absorption of mixing water. The fine aggregate was first poured into the mixer, followed by the cement, fly ash, and CCW. They were then allowed to mix for about $30 \mathrm{~s}$. After that, the coarse aggregate and half of the mixing water was added, and the mixing continued. The superplasticizer was mixed with the other half of the mixing water and was poured gently to the concrete in the mixer. The mixing was continued for about 2 min until a completely homogenous paste was achieved. The mixing was carried out at a room temperature of $20 \pm 5^{\circ} \mathrm{C}$ and controlled relative humidity. Immediately after mixing, the fresh concrete was casted into the molds. Prior to casting, the molds were cleaned and oiled for ease of demolding. The samples were then air dried for $24 \mathrm{~h}$ at room temperature before demolding. After demolding, the samples were fully immersed in a clean water for the curing periods prior to testing.

The durability test was carried out in accordance with ASTM C642 [35]. The $100 \mathrm{~mm}$ cube specimen, after curing for 28 days, was weighed before being dipped in acid, and was reweighed after 3,7 , and 28 days. $\mathrm{H}_{2} \mathrm{SO}_{4}$ was used as the acidic medium while $\mathrm{MgSO}_{4}$ was used as the salt medium. The choice of these chemicals was made based on its high reactivity compared to other acids and salt; therefore, it can be considered when designing structures for worst-case scenarios in terms of exposure to high-acid or salt-prone environments. For each mix, three samples were tested, and the mean values were recorded. Cubes were weighed and then subjected to heat for one hour each at a temperature of $100{ }^{\circ} \mathrm{C}, 200{ }^{\circ} \mathrm{C}, 300{ }^{\circ} \mathrm{C}, 400{ }^{\circ} \mathrm{C}$, and $500{ }^{\circ} \mathrm{C}$, respectively, allowed to cool, and then reweighed before being subjected to a compressive strength test. The compressive strength test was carried out on the $100 \mathrm{~mm}$ cube samples in accordance with BS EN 12390-3 [36] using a universal testing machine of $2000 \mathrm{kN}$ capacity. Water absorption of the $100 \mathrm{~mm}$ cube specimens was also tested after a 28-day curing period in accordance with the method outlined in ASTM C642 [35].

\section{Results and Discussions}

\subsection{Durability of SCC on Immersion in Acid Media}

The effect of acid attack on SCC mixes was measured by immersion in $\mathrm{H}_{2} \mathrm{SO}_{4}$ concentration and the results are presented in Figures 2 and 3. It can clearly be seen that sulphate decreased the weight of all the SCC mixes, as presented in Figures 2 and 3. The decrease in weight $(\%)$ can be attributed to the large amount of $\mathrm{CaO}$ in the $\mathrm{CCW}$ and Portland cement and its hydration product $\mathrm{Ca}(\mathrm{OH})_{2}$, which is primarily responsible for the poor resistance of SCC exposed to acidic attack [37]. The weights of all of the SCC mixes were reduced with the increasing of the immersion period in $\mathrm{H}_{2} \mathrm{SO}_{4}$. This was a result of continuous attack by the sulphate over time. However, the attack by sulphate was reduced for mixes containing fly ash, as shown in Figure 3. At 28-day immersion age, the M10CR10C mix had the greatest resistance to acid attack for the mixes not containing fly ash, while the M20CR40F10C mix had the greatest resistance to acid attacks for mixes with fly ash, with a $16 \%$ reduction in acid penetration upon incorporation of HVFA to the mix. On the other hand, the M20CR0C mix had the least resistance to acid attack for mixes containing no fly ash, while the M0CR40F0C mix had the least resistance to acid attack for mixes with a $40 \%$ replacement of cement with fly ash, showing a $23 \%$ reduction in acid penetration upon incorporation of fly ash to the mix. 


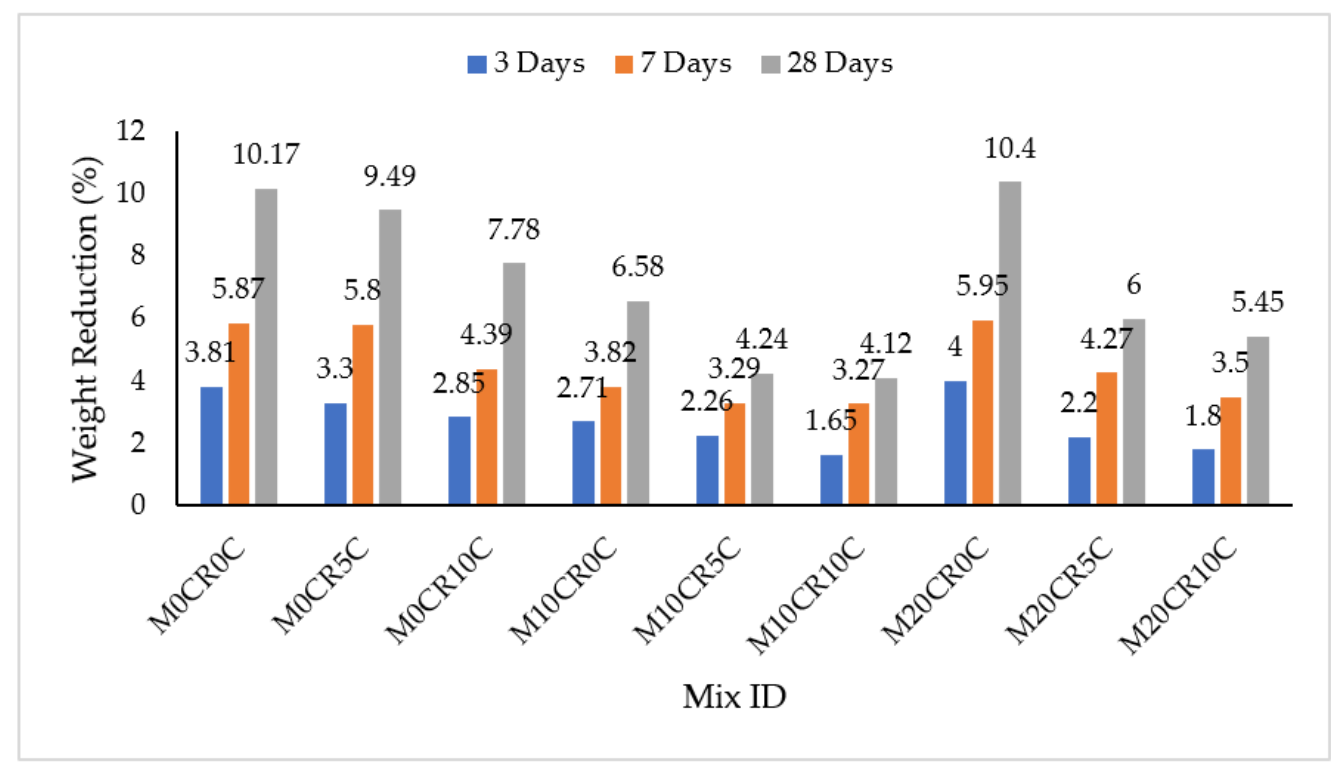

Figure 2. Immersion periods in $\mathrm{H}_{2} \mathrm{SO}_{4}$ for SCC mixes containing $\mathrm{CR}$ and CCW.

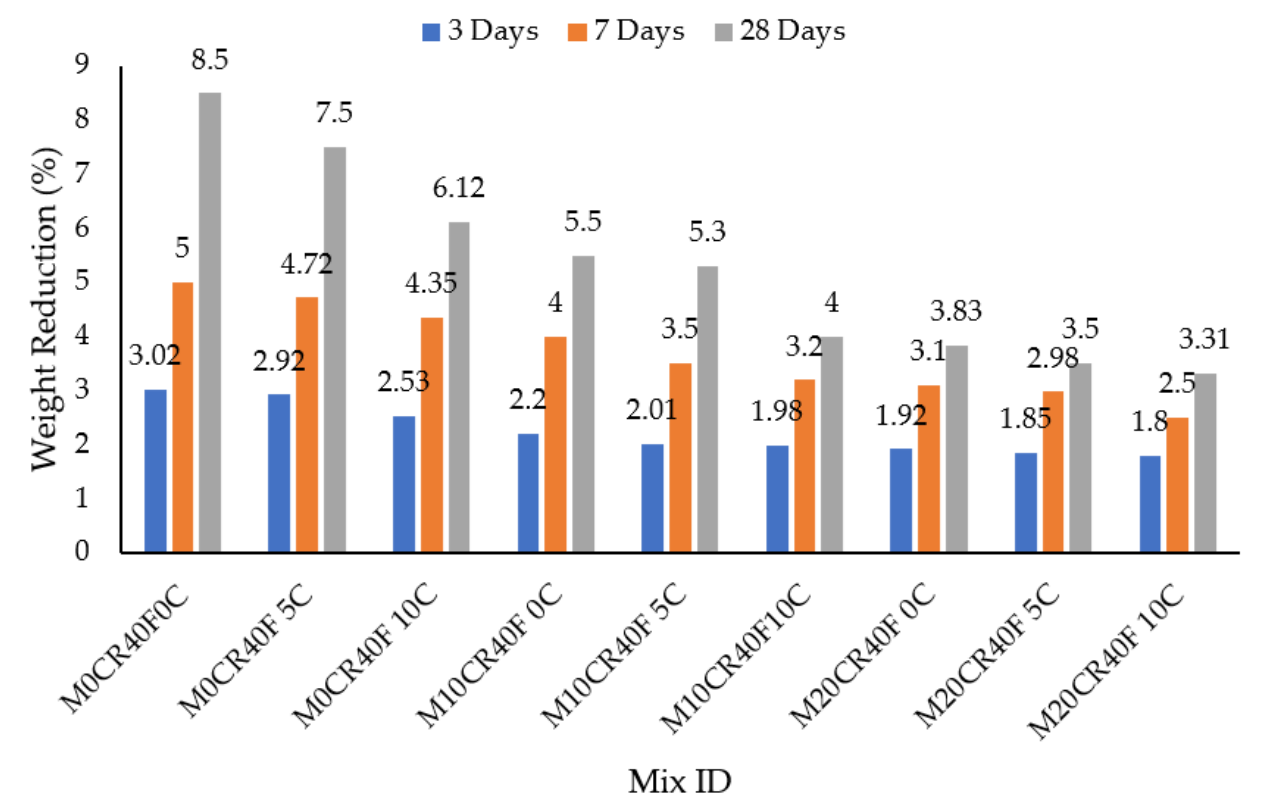

Figure 3. Immersion periods in $\mathrm{H}_{2} \mathrm{SO}_{4}$ for SCC mixes containing fly ash, $\mathrm{CR}$, and CCW.

The reason for the improvement could be attributed to the pozzolanic reactivity of fly ash in the mix. In addition, the better finishing surface and the minimal voids on the concrete surface of the specimens containing fly ash led to lower penetration of the acid solution into the interior of the concrete and improved its resistance against acid attack [38]. This observation is similar to that of Dhiyaneshwaran et al. [37]. In contrast, attack by sulphate was increased with the increment in the percentage replacement of fine aggregate with CR for mixes without fly ash. This was due to the presence of the micro voids in the samples, which gave room for more penetration of the immersed media. The higher the quantity of the content of the CR, the greater the number of micro voids present, giving rise to more expansions. This is similar to the finding of $\mathrm{Xu}$ et al. [39]. It can be seen that the addition of fly ash corrected the sulphate attack associated with the replacement of aggregate with CR for the mix with the least penetration, namely M20CR40F10C. 
The addition of CCW to SCC mixes with and without fly ash decreased its resistance to acid attack at all ages of curing, as measured by immersion in $\mathrm{H}_{2} \mathrm{SO}_{4}$ solution. This can be seen in Figures 2 and 3, where mixes containing higher CCW exhibit lower weight reduction. For instance, compared to the control mix (M0CR0C), the weight losses for mixes M0CR5C and M0CR10C were lower by $6.69 \%$ and $23.50 \%$ at 28 days, respectively. For mixes with fly ash, the M0CR40F5C and M0C40F10C were lower by $11.76 \%$ and $28 \%$, respectively, at 28 days. This weight reduction due to CCW was attributed to the high amount of $\mathrm{CaO}$ in the $\mathrm{CCW}$, thereby providing excess $\mathrm{Ca}(\mathrm{OH})_{2}$ in the cement matrix. These calcium compounds are readily attacked by the $\mathrm{H}_{2} \mathrm{SO}_{4}$, which is a strong acid [40]. Similar findings have been reported by Sata et al. [41] and Hanjitsuwan et al. [40], namely a decreased acid resistance of concrete containing CCW as a binder material. For mixes containing $40 \%$ fly ash, the reductions in acid attack (sulphate resistance) of the SCC mixes were lower compared to the mixes without fly ash. This can be observed by comparing the values of weight reductions in Figures 2 and 3. This is attributable to the fact that fly ash decreased the calcium content in the cement matrix via a pozzolanic reaction between the $\mathrm{SiO}_{2}$ from the fly ash with $\mathrm{Ca}(\mathrm{OH})_{2}$ from the CCW to generate more C-S-H gels.

\subsection{Immersion in Salt Media}

The effect of salt attack on the SCC mixes was determined by immersing the SCC in a $5 \%$ concentration of $\mathrm{MgSO}_{4}$, and the results are presented in Figures 4 and 5. The weight of all the SCC blends was reduced with an increase in immersion age in the $\mathrm{MgSO}_{4}$. This was a result of a continuous attack by the sulphate with time, but the rate of the attack was slower compared to the attack by $\mathrm{H}_{2} \mathrm{SO}_{4}$. On the other hand, the durability performance of the SCC mixes with or without fly ash in terms of salt resistance decreased with the increment in the partial replacement of fine aggregate using CR. For the mix without fly ash, namely mix M10CR0C, there were reductions in weight by $49.40 \%, 29.45 \%$, and $26.62 \%$ at 3 , 7 , and 28 days, respectively, compared to the control mix (M0CR0C). For mixes with fly ash, the weight reductions of mix M10CR40F0C were lower by $26.98 \%, 4.61 \%$, and $17.98 \%$ at 3, 7, and 28 days, respectively, compared to mix M0CR40F0C. Similarly for mix M20CR40F0C, the weight losses were lower than that of M0CR40F0C by $47.62 \%, 9.87 \%$, and $21.49 \%$ at 3 , 7 , and 28 days, respectively. This reduction in salt resistance due to CR was attributed to increased porosity in the hardened cement matrix and the weak interfacial transition zone caused by the CR in the cement matrix. This further instigated the formation of internal pressure by the sulfate-related crystal growth, i.e., the formation of ettringite and gypsum due to the $\mathrm{MgSO}_{4}$; this adversely affected the integrity of the SCC through the further formation of internal cracks, and the escalation of the pores, which was caused by the CR. This consequently resulted in decreased resistance to salt attack $\left(\mathrm{MgSO}_{4}\right)$ [42].

The addition of CCW to SCC mixes without fly ash further decreased the weight loss due to immersion in $\mathrm{MgSO}_{4}$ at all ages of curing. At 28 days, the weight losses of mixes M0CR5C, M0CR10C, and M20CR10C were lower by 22.3\%, 32.01\%, and 46.04\%, respectively, in comparison to the control mix (MOCR0C). Similarly, for some mixes with fly ash, the weight reduction due to immersion in $\mathrm{MgSO}_{4}$ decreased with the addition of CCW. At 28 days, the weight losses for mixes M0CR40F10C, M10CR40F5C, and M10CR40F10C were lower by $14.47 \%, 18.86 \%, 34.21 \%$. The reduction in $\mathrm{MgSO}_{4}$ resistance caused by CCW can be attributed to the high $\mathrm{Ca}(\mathrm{OH})_{2}$ generated by the $\mathrm{CCW}$ in the cement matrix. This $\mathrm{Ca}(\mathrm{OH})_{2}$ reacts with the $\mathrm{MgSO}_{4}$ to liberate the hydration of $\mathrm{C}_{3} \mathrm{~S}$ and $\mathrm{C}_{2} \mathrm{~S}$ in the cement, thereby instigating gypsum formation, leading to magnesium-gypsum attack on the C-S-H formed during cement hydration, thus causing deterioration [43]. By comparing Figure 4 with Figure 5, it can be observed that the resistance of SCC to salt attack, i.e., immersion in $\mathrm{MgSO}_{4}$, was higher for mixes with fly ash compared to mixes without fly ash. This can be attributed to the pozzolanic reaction of fly ash with $\mathrm{CCW}$, i.e., $\mathrm{SiO}_{2}$ from fly ash reacting with the excess $\mathrm{Ca}(\mathrm{OH})_{2}$ produced from CCW to generate more C-S-H gels. This consequently reduced the amount of $\mathrm{Ca}(\mathrm{OH})_{2}$ that reacted with $\mathrm{MgSO}_{4}$ to form magnesium based-gypsum, which caused deterioration of the cement matrix [43]. 


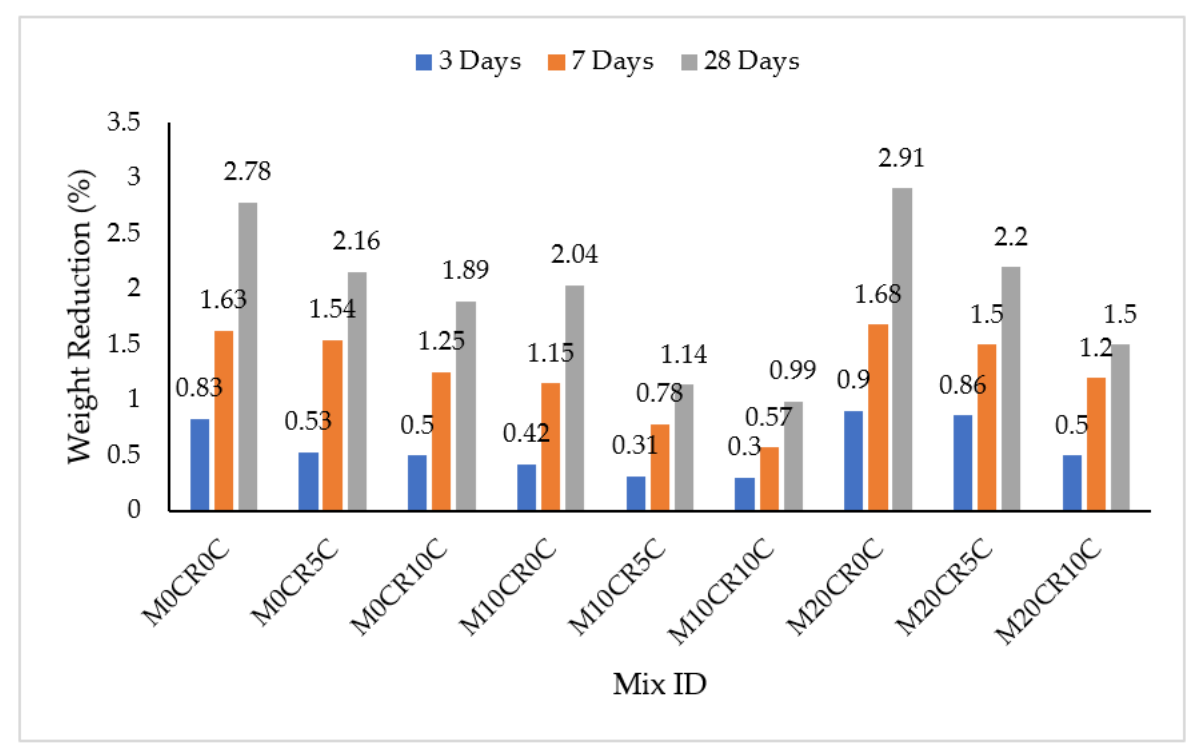

Figure 4. Immersion periods in $\mathrm{MgSO}_{4}$ for SCC mixes containing CR and CCW.

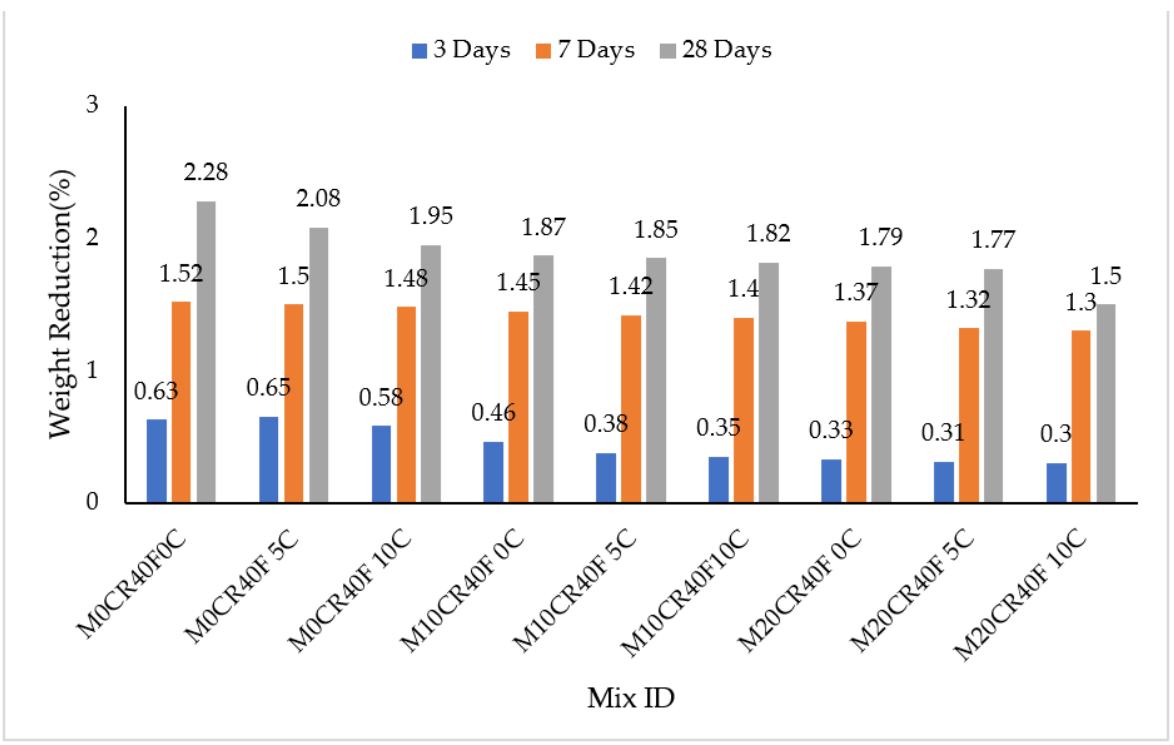

Figure 5. Immersion periods in $\mathrm{MgSO}_{4}$ for SCC mixes containing fly ash, CR, and CCW.

\subsection{Effect of Elevated Temperature on SCC Mixes}

Figures 6 and 7 shows the percentage weight reduction in the SCC mixes at varied temperatures. These figures show that the SCC blends lost more of their weight as the $\mathrm{CR}$ content was increased. This observation was noticed as the temperature increased, as shown in the aforementioned figures. The reduction in weight could be a result of spalling caused by internal water pressure at about $300^{\circ} \mathrm{C}$ and during the dehydration of hydrated calcium silicate hydrate, which is known to increase internal stresses and induces micro-cracks [44]. The decrease in weight could also have resulted from the expulsion of the excess pore water in the SCC mix [45]. Generally, the addition of $40 \%$ optimum fly ash yielded a further decrease in the weight of the mixes by $6 \%$, when compared with the mix without fly ash (M20CR10C) at $500{ }^{\circ} \mathrm{C}$ and the M20CR40F10C mix for mixes with fly ash. This confirms a similar result obtained by Fawzy et al. [46] after heating at $200{ }^{\circ} \mathrm{C}$ and below. 


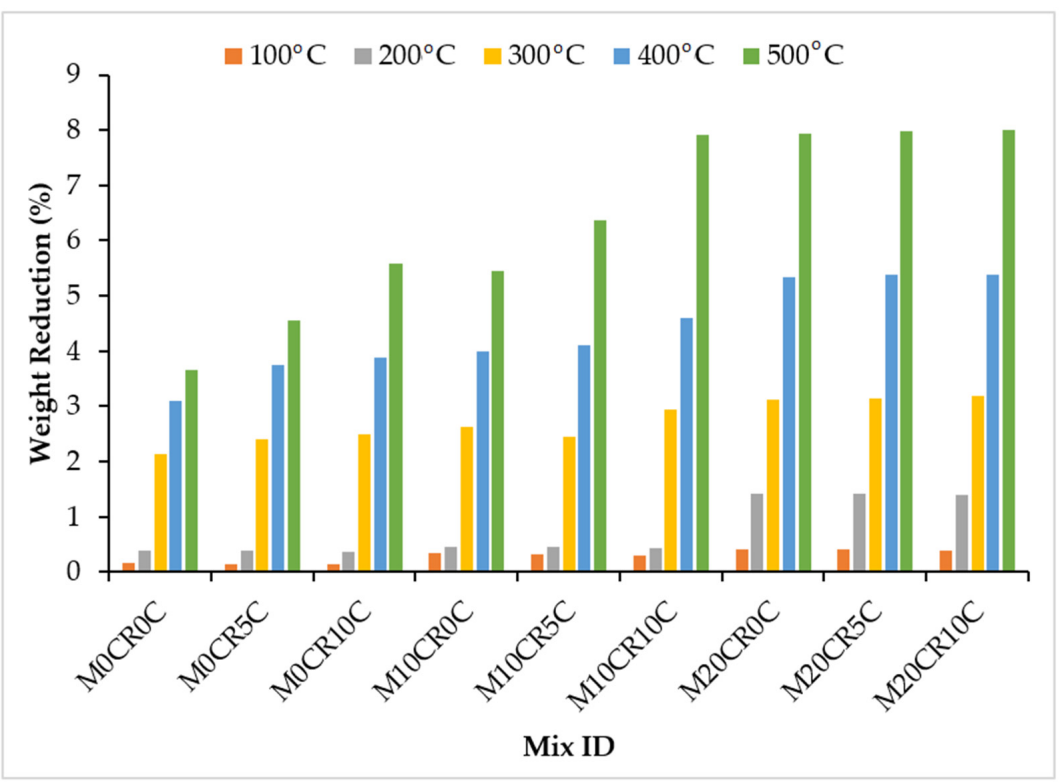

Figure 6. Effects of elevated temperature on weight of SCC mixes containing CR and CCW.

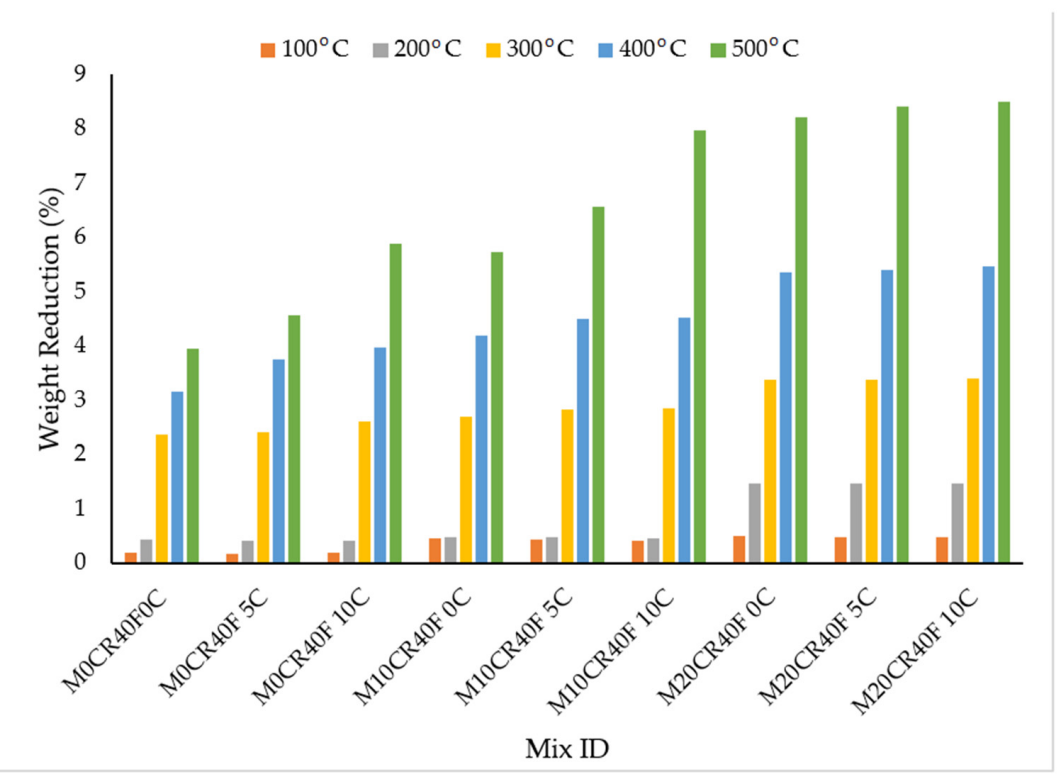

Figure 7. Effects of elevated temperature on weight of SCC mixes containing fly ash, CR, and CCW.

The weight reduction was reduced slightly with the increase in the addition of CCW due to the reaction of $\mathrm{CCW}$ with the free lime, which produced more CSH and $\mathrm{CAH}$. The samples exhibited no sign of explosive spalling, but the test samples showed cracks on their surface, which were increased as the temperature increased due to water evaporation, drying shrinkage, and thermal expansion that mounted stress on the concrete, resulting in cracks [22].

In addition, the color of the SCC control mix became brighter because of the water loss at high temperatures, while the mix containing CR was changed from light grey to brownish-black due to the dispersion of carbon black, which is a part of the rubber tires, with the increase in temperature from $400{ }^{\circ} \mathrm{C}$ to $500{ }^{\circ} \mathrm{C}$. Certain colors correspond with a specific temperature range, which is an important indicator of the maximum temperature that the structure can be exposed to. At temperatures below $400{ }^{\circ} \mathrm{C}$, the concrete color did not change noticeably, as shown in Figure 8. This observation is similar to the findings of Fawzy et al. [46]. 
Below $400{ }^{\circ} \mathrm{C}$

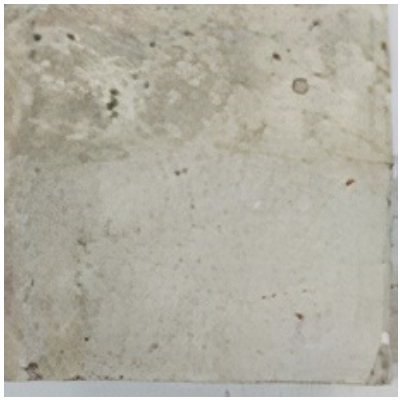

(a) MOCR0C
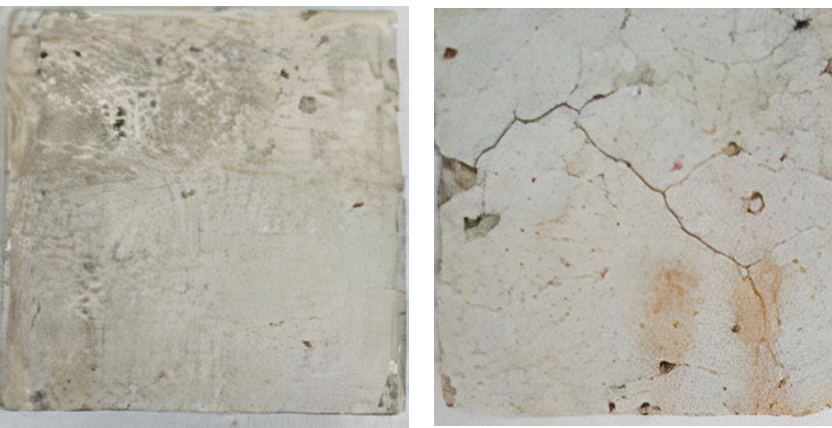

(b) M0CR40F0C
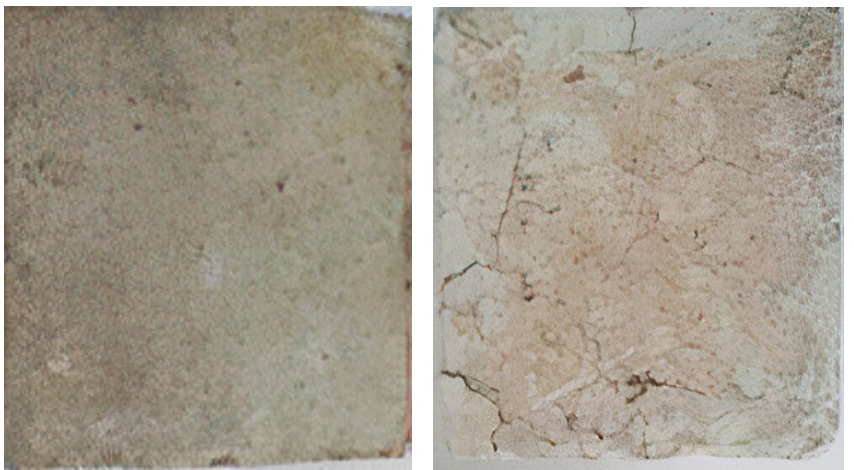

(c) MOCR5C
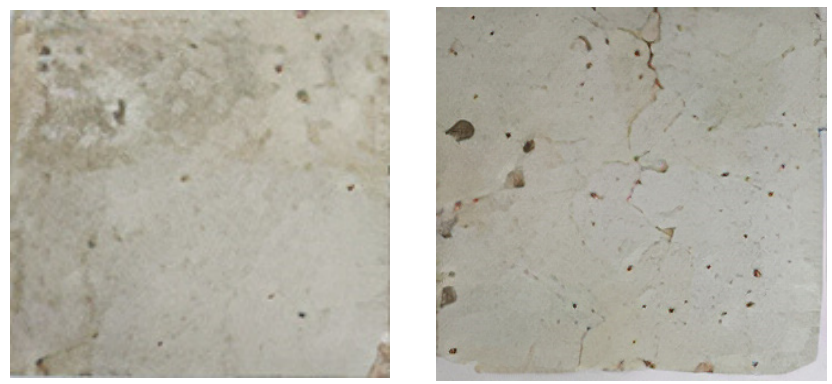

(d) M0CR40F5C
Below $400{ }^{\circ} \mathrm{C}$

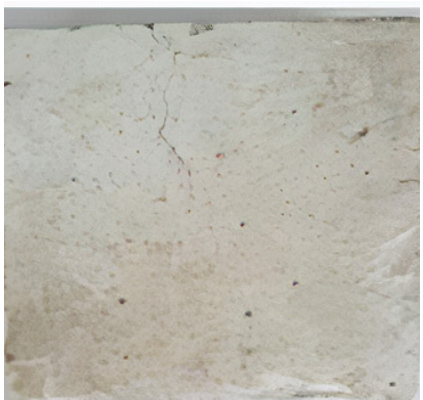

(e) M10CR5C
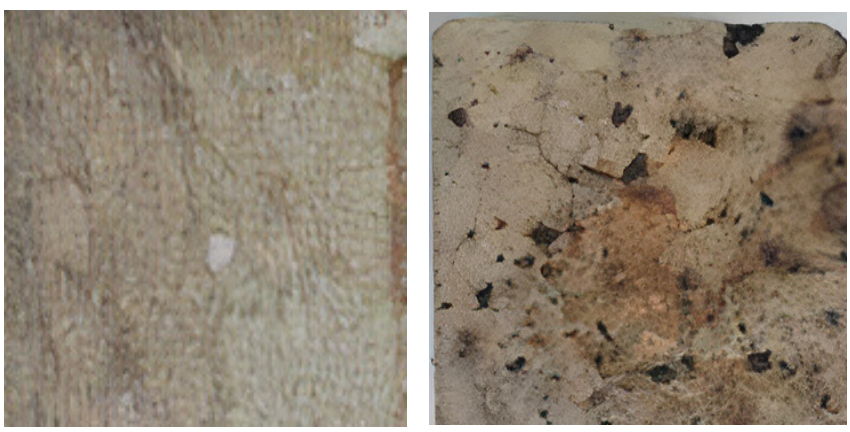

(f) M10CR40F5C
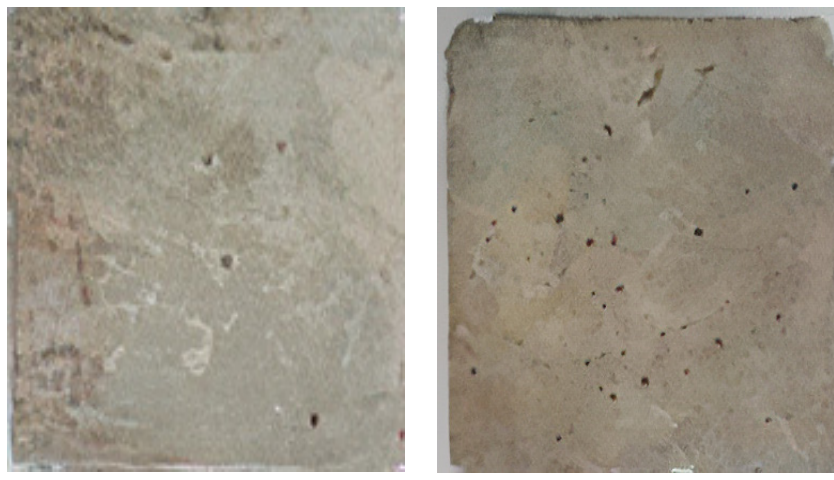

(g) M20CR10C
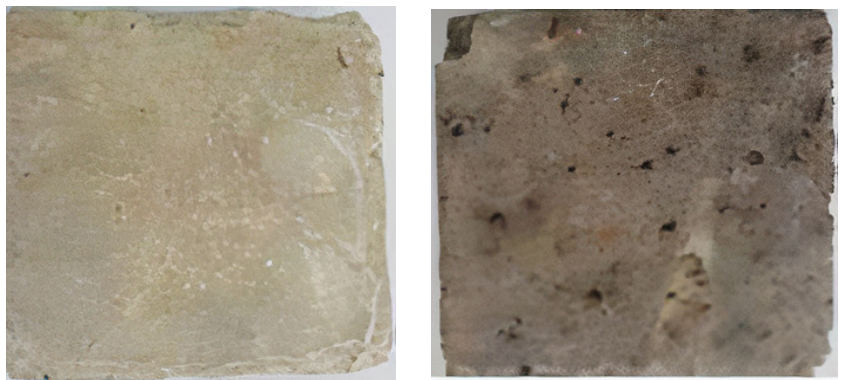

(h) M20CR40F10C

Figure 8. Samples' color changes after heating at elevated temperature. (a) MOCR0C (b) M0CR40F0C (c) M0CR5C (d) M0CR40F5C (e) M10CR5C (f) M10CR40F5C (g) M20CR10C (h) M20CR40F10C. 
The compressive strengths of the various replacements when subjected to elevated temperatures of 100, 200, 300,400, and $500{ }^{\circ} \mathrm{C}$ are graphically represented in Figures 9 and 10. The compressive strength of SCC mixes was decreased with the increase in the temperature. A slight increase in the compressive strength was observed for all mixes and their replicas containing fly ash at control temperature $\left(27^{\circ} \mathrm{C}\right)$ except for the M10CR0C, M10CR0C, M10CR10C, M20CR0C, and M20CR5C mixes, which experienced increases in compressive strength at $100{ }^{\circ} \mathrm{C}$ before a further decrease. This was due to the reduction in the calcium hydroxide and un-hydrated area fraction aided by autoclaving (heat healing effect), which enhanced the microstructure [47]. The highest loss in compressive strength was observed at the temperature between 300 and $400{ }^{\circ} \mathrm{C}$ due to the calcium silicate hydrate $(\mathrm{C}-\mathrm{S}-\mathrm{H})$. The incorporation of $\mathrm{CR}$ to the mix also reduced the rate of compressive strength loss because the melted rubber particle at $200{ }^{\circ} \mathrm{C}$ left space for water vapor to escape and, thus, helped to release the pore pressure. This outcome is similar to the findings of Huang et al. [48]. Generally, it can be observed that CCW slightly increased the compressive strength up to $200{ }^{\circ} \mathrm{C}$ and then decreased it after that. This increase was a result of the reaction of $\mathrm{CCW}$ with the free lime to produce more $\mathrm{CSH}$ and $\mathrm{CAH}$, which deposited in the pore system, and also occurred because of the higher volume of $\mathrm{CSH}$ and $\mathrm{CAH}$ phases formed and the reduction in $\mathrm{Ca}(\mathrm{OH})_{2}$ content.

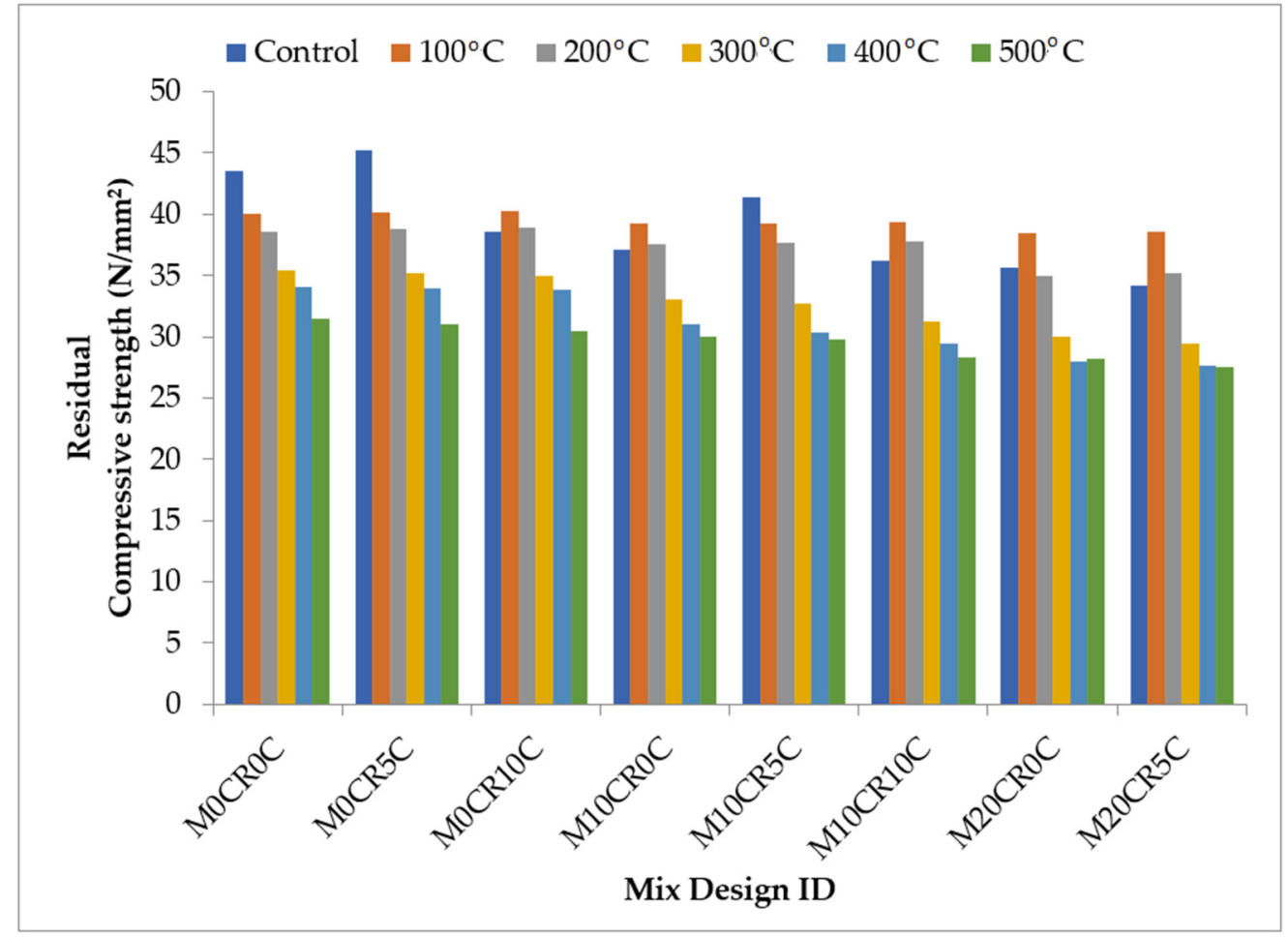

Figure 9. Effect of elevated temperature on the compressive strength of SCC mixes containing CR and CCW. 


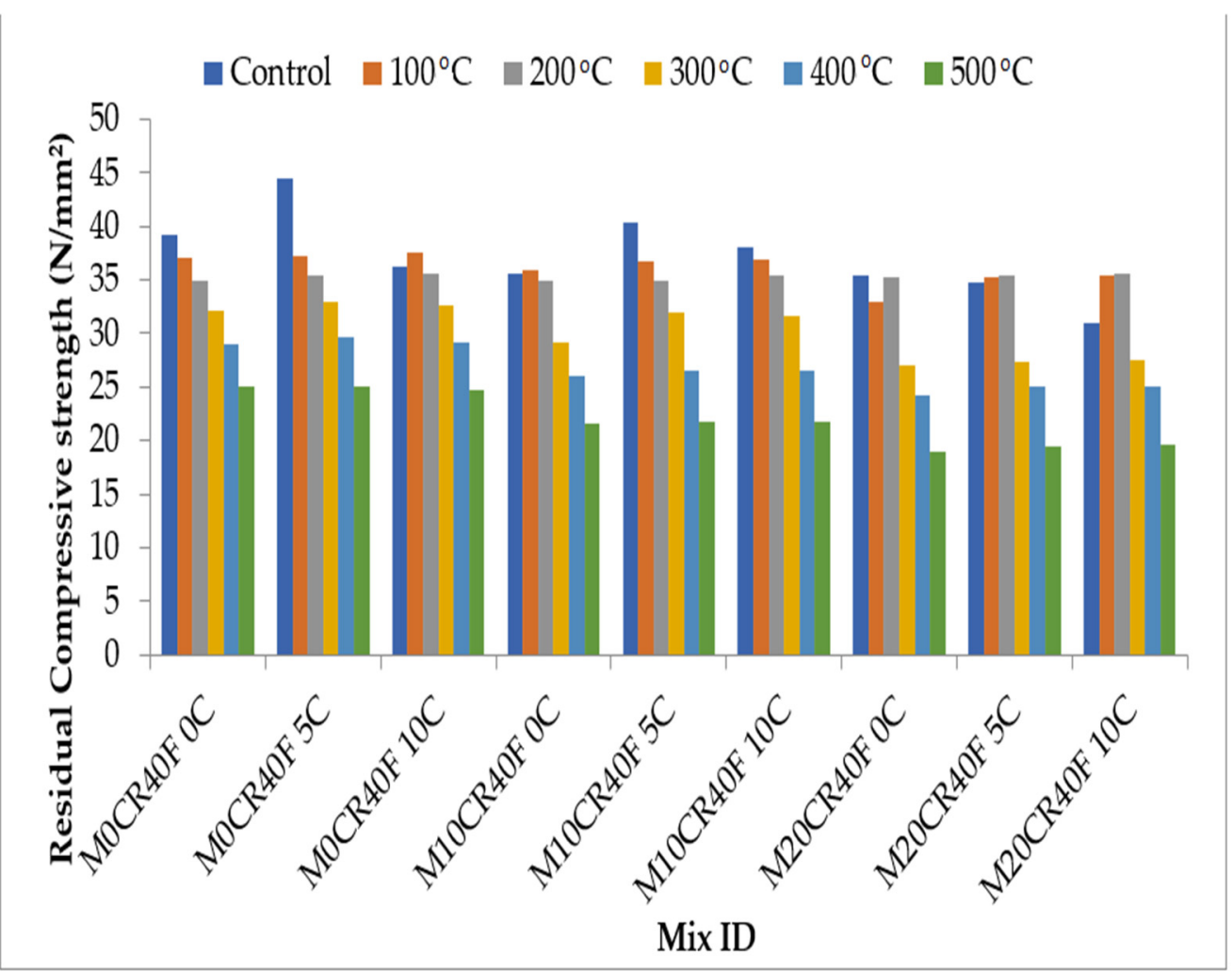

Figure 10. Effect of elevated temperature on the compressive strength of SCC mixes containing fly ash, CR, and CCW.

\subsection{Water Absorption}

Figures 11 and 12 show the water absorption capacity of the various SCC mixes. The water absorption of the SCC mixes increased with the increment in the partial replacement of fine aggregate with CR for the mixes with and without fly ash. For mixes without fly ash, the water absorption of mixes M10CR0C and M20R0C was higher, by $36.21 \%$ and $62.64 \%$, respectively, compared to mix M0CR0C (control mix). Similarly, for mixes with fly ash, the water absorption of mixes M10CR40F0C and M20CR40F0C was lower, by $24.26 \%$ and $30.77 \%$, respectively, compared to mix MOCR40F0C. The reduction in water absorption due to $\mathrm{CR}$ incorporation can be attributed to the hydrophobic nature of $\mathrm{CR}$, causing it to entrap air on its surface during mixing. When the concrete dried up, the entrapped air left excess voids in the cement matrix, thereby increasing porosity and, hence, leading to higher water absorption $[7,8]$. The addition of CCW slightly increased the water absorption of mixes without fly ash. For instance, the water absorption of mix M0CR5C was slightly higher than that of the control (by 1.15\%), while mix MOCR10C had the same water absorption value as the control mix (MOCROC). Furthermore, the addition of CCW partially mitigated the negative effect of CR on the water absorption of the SCC mixes with or without fly ash. This can be observed by comparing the water absorption value of M20CR0C $(2.83 \%)$ with that of M20CR5C (2.19\%) and M20CR10C (2.15\%), and that of mix M20CR40F0C $(2.21 \%)$ with M20CR40F5C (2.11\%) and M20CR40F10C (2.13\%). The reduction in water absorption due to the addition of CCW can be attributed to its finer sizes, thereby acting as a filler material and filling the pores created by the $\mathrm{CR}$ and, hence, reducing the water absorption. Another reason could be the higher reactivity of $\mathrm{CCW}$, thereby allowing it to react with cement hydration products to form more C-S-H gels, which filled the nanopores in the cement matrix and, hence, reduced the water absorption [4,6]. By comparing Figure 11 with Figure 12, it can be seen that for the SCC with fly ash, mixes with same amount of $\mathrm{CR}$ and CCW had lower water absorption values compared to the SCC mixes without fly ash with the same amount $\mathrm{CR}$ and CCW. This was due to the pozzolanic reaction between the $\mathrm{SiO}_{2}$ from fly ash and $\mathrm{Ca}(\mathrm{OH})_{2}$ from CCW to generate excess C-S-H gels, which filled 
up the pores in the cement matrix and the decreased water content, similarly to the in the SCC without fly ash. Therefore, it can be concluded that the incorporation of CCW and fly ash reduces the water absorption due to the refined pore system created by fly ash and the CCW microstructure. Overall, the water absorption of the SCC blends containing the replacements in the right proportion resulted in a more durable SCC. This is in line with the research conducted by Mohammed and Adamu [8].

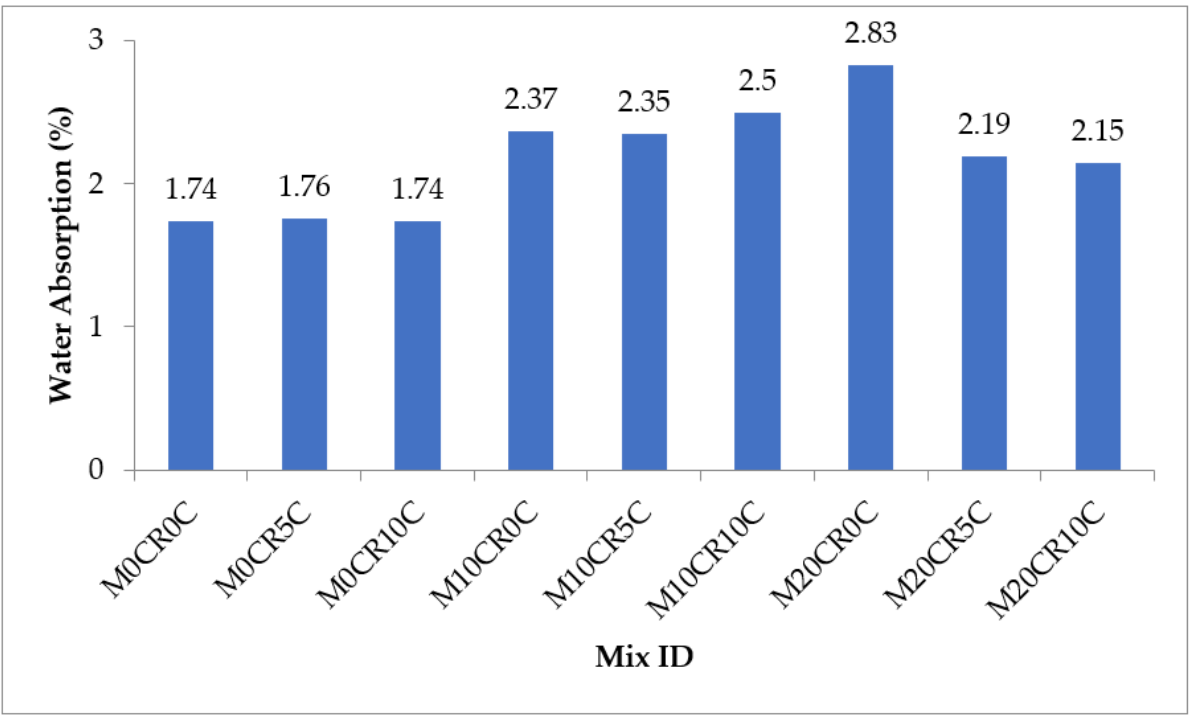

Figure 11. Water absorption capacity of SCC mixes containing CR and CCW.

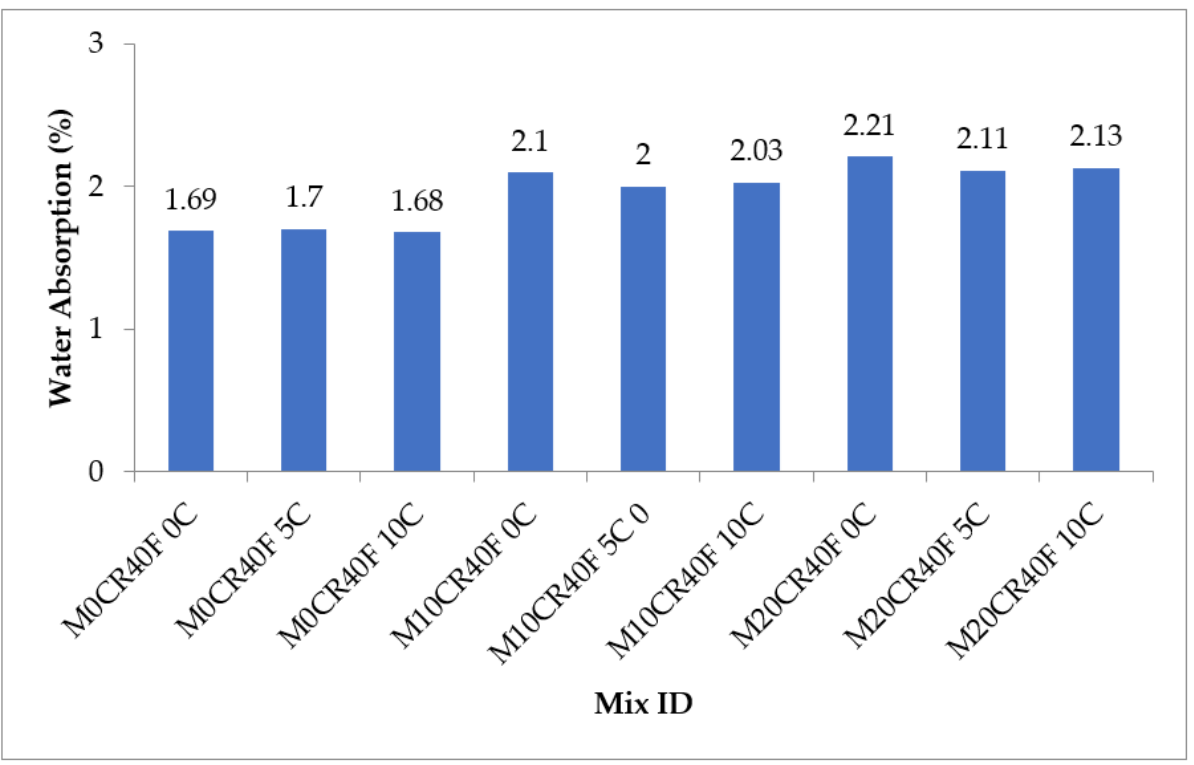

Figure 12. Water absorption of SCC mixes containing fly ash, CR, and CCW.

\section{Conclusions}

In this study, the effect of the partial replacement of fine aggregate with $C R$, and of cement with CCW, on the durability performance of SCC in both normal and adverse conditions was investigated. Furthermore, the effect of $C R$ as an aggregate replacement, and of CCW as a cement replacement, on a blend of SCC made produced $40 \%$ fly ash as a supplementary cementitious material was evaluated. Based on the experimental results and analysis, the following conclusions can be drawn. 
(1) The resistance of the SCC against acid attack, as measured by immersion in $\mathrm{H}_{2} \mathrm{SO}_{4}$, and the resistance against salt medium, as measured by immersion in $\mathrm{MgSO}_{4}$, all improved with the use of fly ash and CCW as supplementary cementitious materials (SCM).

(2) The partial replacement of fine aggregate with CR in SCC mixes significantly reduced its resistance against acid and salt attacks. This negative effect was more severe in the SCC mixes without fly ash and CCW.

(3) The resistance of the SCC mixes against heat decreased the replacement of $40 \%$ cement with fly ash beyond a temperature of $200{ }^{\circ} \mathrm{C}$. Furthermore, the heat resistance of the SCC mixes decreased with the increase in the partial replacement of fine aggregate with CR, and the use of CCW as SCM.

(4) The optimum temperature for the blends was found to be $400{ }^{\circ} \mathrm{C}$; however, the water absorption was decreased with the increasing of the fly ash content and was increased with the increasing of the CR content, but with a rapid increase beyond $10 \%$ addition of CR.

(5) Fly ash is recommended for use as a SCM to improve the resistance of SCC mixes containing CR as a partial replacement of fine aggregates for use in acidic and salty environments.

Author Contributions: Conceptualization, S.E.K. and M.A.; methodology, S.E.K., A.M. and I.I.O.; software, S.E.K. and M.A.; validation, M.A. and A.M.; formal analysis, S.E.K., M.A. and I.I.O.; investigation, M.A. and Y.E.I.; resources, M.A. and Y.E.I.; data curation, S.E.K., M.A. and A.M.; writing-original draft preparation, S.E.K. and M.A.; writing — review and editing, Y.E.I.; visualization, M.A.; supervision, M.A. and Y.E.I.; project administration, Y.E.I.; funding acquisition, Y.E.I. All authors have read and agreed to the published version of the manuscript.

Funding: This research was supported by the Structures and Materials (S\&M) Research Lab of Prince Sultan University, Saudi Arabia. Furthermore, the authors acknowledge the support of Prince Sultan University in paying the article processing charges (APC) of this publication.

Institutional Review Board Statement: Not applicable.

Informed Consent Statement: Not applicable.

Data Availability Statement: The data presented in this study are available on request from the corresponding author.

Acknowledgments: The authors wish to acknowledge the structures and materials laboratory (S\&M $\mathrm{Lab}$ ) of the College of Engineering, Prince Sultan University, Riyadh, Saudi Arabia, and the Department of Civil Engineering Laboratory, Bayero University Kano, Nigeria, for their vital support.

Conflicts of Interest: The authors declare no conflict of interest.

\section{References}

1. Obianyo, I.I.; Mahamat, A.A.; Stanislas, T.T.; Ihekweme, G.O.; Kelechi, S.E.; Onyelowe, K.C.; Onwualu, A.P.; Soboyejo, A.B. Production and utilization of earth-based bricks for sustainable building applications in Nigeria: Status, benefits, challenges and way forward. J. Build. Pathol. Rehabil. 2021, 6, 37. [CrossRef]

2. Bolden, J.; Abu-Lebdeh, T.; Fini, E. Utilization of recycled and waste materials in various construction applications. Am. J. Environ. Sci. 2013, 9, 14-24. [CrossRef]

3. Roy, K.; Akhtar, A.; Sachdev, S.; Hsu, M.; Lim, J.; Sarmah, A. Development and characterization of novel biochar-mortar composite utilizing waste derived pyrolysis biochar. Int. J. Sci. Eng. Res. 2017, 8, 1912-1919.

4. Adamu, M.; Ayeni, K.O.; Haruna, S.I.; Mansour, Y.E.-H.I.; Haruna, S. Durability performance of pervious concrete containing rice husk ash and calcium carbide: A response surface methodology approach. Case Stud. Constr. Mater. 2021, 14, e00547. [CrossRef]

5. Adamu, M.; Olalekan, S.S.; Aliyu, M.M. Optimizing the Mechanical Properties of Pervious Concrete Containing Calcium Carbide and Rice Husk Ash Using Response Surface Methodology. J. Soft Comput. Civ. Eng. 2020, 4, 95-118.

6. Adamu, M.; Ibrahim, Y.E.; Al-Atroush, M.E.; Alanazi, H. Mechanical Properties and Durability Performance of Concrete Containing Calcium Carbide Residue and Nano Silica. Materials 2021, 14, 6960. [CrossRef]

7. Adamu, M.; Mohammed, B.S.; Liew, M.S. Mechanical properties and performance of high volume fly ash roller compacted concrete containing crumb rubber and nano silica. Constr. Build. Mater. 2018, 171, 521-538. [CrossRef]

8. Mohammed, B.S.; Adamu, M. Mechanical performance of roller compacted concrete pavement containing crumb rubber and nano silica. Constr. Build. Mater. 2018, 159, 234-251. [CrossRef] 
9. Hilal, N.N. Hardened properties of self-compacting concrete with different crumb rubber size and content. Int. J. Sustain. Built Environ. 2017, 6, 191-206. [CrossRef]

10. Najim, K.B.; Hall, M.R. Workability and mechanical properties of crumb-rubber concrete. Proc. Inst. Civ. Eng.-Constr. Mater. 2013, 166, 7-17. [CrossRef]

11. Turgut, P.; Yesilata, B. Physico-mechanical and thermal performances of newly developed rubber-added bricks. Energy Build. 2008, 40, 679-688. [CrossRef]

12. Rajamony Laila, L.; Gurupatham, B.G.A.; Roy, K.; Lim, J.B. Influence of super absorbent polymer on mechanical, rheological, durability, and microstructural properties of self-compacting concrete using non-biodegradable granite pulver. Struct. Concr. 2021, 22, E1093-E1116. [CrossRef]

13. Rajamony Laila, L.; Gurupatham, B.G.A.; Roy, K.; Lim, J.B.P. Effect of super absorbent polymer on microstructural and mechanical properties of concrete blends using granite pulver. Struct. Concr. 2021, 22, E898-E915. [CrossRef]

14. Surya, T.R.; Prakash, M.; Satyanarayanan, K.; Celestine, A.K.; Parthasarathi, N. Compressive strength of self compacting concrete under elevated temperature. Mater. Today Proc. 2021, 40, S83-S87. [CrossRef]

15. Santos, S.; Da Silva, P.; De Brito, J. Self-compacting concrete with recycled aggregates-A literature review. J. Build. Eng. 2019, 22, 349-371. [CrossRef]

16. Yehia, S.; Douba, A.; Abdullahi, O.; Farrag, S. Mechanical and durability evaluation of fiber-reinforced self-compacting concrete Constr. Build. Mater. 2016, 121, 120-133. [CrossRef]

17. Babu, A.; Nazeer, M. Study on the Strength and Durability Properties of Ternary Blended Concrete. Int. J. Eng. Res. Technol. (IJERT) 2016, 3, 155-160.

18. Danish, P.; Ganesh, M.G. Behaviour of self-compacting concrete using different mineral powders additions in ternary blends. Rev. Romana Mater. 2020, 50, 232-239.

19. Bušić, R.; Miličević, I.; Šipoš, T.K.; Strukar, K. Recycled rubber as an aggregate replacement in self-compacting concrete-literature overview. Materials 2018, 11, 1729. [CrossRef]

20. Adamu, M.; Mohammed, B.S.; Shafiq, N.; Liew, M.S. Durability performance of high volume fly ash roller compacted concrete pavement containing crumb rubber and nano silica. Int. J. Pavement Eng. 2020, 21, 1437-1444. [CrossRef]

21. Bayuaji, R.; Putri, N.; Ming, L.Y.; Mortar, N.A.M. Study Of The Utilization Of Carbide Waste And Fly Ash On Geopolymer Paste. In IOP Conference Series: Materials Science and Engineering; IOP Publishing: Bristol, UK, 2020; p. 012042.

22. Abdurra'uf, M.G.; Ogork, E.; Haruna, S.I. Effect of calcium carbide wastes as admixture in mortar. Sch. J. Eng. Technol. 2017, 5, 655-660.

23. Joel, M.; Edeh, J.E. Soil modification and stabilization potential of calcium carbide waste. In Advanced Materials Research; Trans Tech Publications Ltd.: Freienbach, Switzerland, 2013.

24. Liu, Y.; Chang, C.-W.; Namdar, A.; She, Y.; Lin, C.-H.; Yuan, X.; Yang, Q. Stabilization of expansive soil using cementing material from rice husk ash and calcium carbide residue. Constr. Build. Mater. 2019, 221,1-11. [CrossRef]

25. Yahyaei, B.; Asadollahfardi, G.; Salehi, A.M. Workability, mechanical, and durability properties of self-compacting concrete using the treated wastewater. Struct. Concr. 2021, 22, E997-E1008. [CrossRef]

26. Mohammed, B.S.; Adamu, M.; Liew, M.S. Evaluating the effect of crumb rubber and nano silica on the properties of high volume fly ash roller compacted concrete pavement using non-destructive techniques. Case Stud. Constr. Mater. 2018, 8, 380-391. [CrossRef]

27. Najim, K.B.; Hall, M.R. Mechanical and dynamic properties of self-compacting crumb rubber modified concrete. Constr. Build. Mater. 2012, 27, 521-530. [CrossRef]

28. Khalil, E.; Abd-Elmohsen, M.; Anwar, A.M. Impact resistance of rubberized self-compacting concrete. Water Sci. 2015, 29 , 45-53. [CrossRef]

29. Adamu, M.; Mohammed, B.S.; Liew, M.S.; Alaloul, W.S. Evaluating the impact resistance of roller compacted concrete containing crumb rubber and nanosilica using response surface methodology and Weibull distribution. World J. Eng. 2019, 16, 33-43. [CrossRef]

30. Yung, W.H.; Yung, L.C.; Hua, L.H. A study of the durability properties of waste tire rubber applied to self-compacting concrete. Constr. Build. Mater. 2013, 41, 665-672. [CrossRef]

31. BS EN 196-6; Cement Density Test. British Standard Institution: London, UK, 2005.

32. ASTM C618; Standard Specification for Coal Fly Ash and Raw or Calcined Natural Pozzolan for Use in Concrete. ASTM International: West Conshohocken, PA, USA, 2019.

33. BS 882; Specification for Aggregates from Natural Sources for Concrete. British Standards Institution: London, UK, 1992.

34. BS 1881-125; Methods for Mixing and Sampling Concrete in the Laboratory, in Testing Concrete. British Standard Institution: London, UK, 2013

35. ASTM C642; Standard Test Method for Density, Absorption, and Voids in Hardened Concrete. ASTM International: West Conshohocken, PA, USA, 2013.

36. BS EN 12390-3; Compressive Strength of Test Specimens, in Testing Hardened Concrete. British Standards Institution: London, UK, 2009.

37. Dhiyaneshwaran, S.; Ramanathan, P.; Baskar, I.; Venkatasubramani, R. Study on durability characteristics of self-compacting concrete with fly ash. Jordan J. Civ. Eng. 2013, 7, 342-352. 
38. Panda, S.; Panigrahi, R.; Narshimam, M. A review on utilization of alkali activated flyash and ggbfs as green concrete. Adalya J. 2019, 8, 91-96

39. Xu, J.; Chen, S.; Yu, H.; Wang, Y. Crumb Rubber Concrete Deterioration Caused by Sulphate Attack. In Proceedings of the 3rd International Conference on Material, Mechanical, and Manufacturing Engineering (IC3ME 2015), Guangzhou, China, 27-28 June 2015.

40. Hanjitsuwan, S.; Phoo-ngernkham, T.; Damrongwiriyanupap, N. Comparative study using Portland cement and calcium carbide residue as a promoter in bottom ash geopolymer mortar. Constr. Build. Mater. 2017, 133, 128-134. [CrossRef]

41. Sata, V.; Sathonsaowaphak, A.; Chindaprasirt, P. Resistance of lignite bottom ash geopolymer mortar to sulfate and sulfuric acid attack. Cem. Concr. Compos. 2012, 34, 700-708. [CrossRef]

42. Diab, A.M.; Elyamany, H.E.; Abd Elmoaty, M.; Sreh, M.M. Effect of nanomaterials additives on performance of concrete resistance against magnesium sulfate and acids. Constr. Build. Mater. 2019, 210, 210-231. [CrossRef]

43. Al-Dulaijan, S.U. Sulfate resistance of plain and blended cements exposed to magnesium sulfate solutions. Constr. Build. Mater. 2007, 21, 1792-1802. [CrossRef]

44. Mohammed, B.S.; Yen, L.Y.; Haruna, S.; Huat, S.; Lim, M.; Abdulkadir, I.; Al-Fakih, A.; Liew, M.; Zawawi, A.; Wan, N.A. Effect of Elevated Temperature on the Compressive Strength and Durability Properties of Crumb Rubber Engineered Cementitious Composite. Materials 2020, 13, 3516. [CrossRef] [PubMed]

45. Sonebi, M.; Ibrahim, R. Assessment of the durability of medium strength SCC from its permeation properties. In Proceedings of the 5th International RILEM Symposium on Self-Compacting Concrete, Ghent, Belgium, 3-5 September 2007; pp. 677-682.

46. Fawzy, H.; Mustafa, S.; Abd El Badie, A. Effect of Elevated Temperature on Concrete Containing Waste Tires Rubber. Egypt. J. Eng. Sci. Technol. 2020, 29, 1-13. [CrossRef]

47. Adefemi, A.; Muhammad, U.; Kebbi, U.M.B.; Olugbenga, S. Effect of Admixture on Fire Resistance of Ordinary Portland Cement Concrete. Civ. Environ. Res. 2013, 3, 302-308.

48. Huang, B.; Li, G.; Pang, S.-S.; Eggers, J. Investigation into waste tire rubber-filled concrete. J. Mater. Civ. Eng. 2004, 16, 187-194. [CrossRef] 